\title{
A fuzzy decision system for new product specification forecast
}

\section{Khadijeh Yousefipour Jeddi}

Dept. of Management, Science and Research Branch, Islamic Azad University, Tehran, Iran

$\triangle$ kh.yousefpour@gmail.com, Published: 15 April 2016

\begin{abstract}
New product development (NPD) requires considering multiple criteria under a hierarchical structure. The evaluation process often involves uncertainty and fuzziness in both the relationships between criteria and the judgments of evaluators. Quality function deployment (QFD) aims to facilitate the NPD process from product conceptualization to production requirements. New Product Specification Forecast System (NPSFS) support product development and used from first matrix of QFD. A case study of a scale producer firm to select the Specification of new product based on data collected from designed questionnaires is given which includes identification \& determination of customers' needs, while looking for technical and engineering characteristics related to their needs. The results are then used to construct houses of quality for QFD, which is incorporated by fuzzy AHP. It is concluded that the proposed decision support system by fuzzy QFD can be used as a powerful tool to select the most suitable specification for new products to satisfy customer's needs.
\end{abstract}

Key Words: Decision support systems (DSS). Fuzzy AHP, Quality function deployment (QFD), New product specification forecast system (NPSFS) and New product development (NPD)

Please cite this article as: Jeddi, K. Y. (2016). A fuzzy decision system for new product specification forecast. International Journal of Business, Management and Social Research, 02(01), 105-113.

This article is distributed under terms of a Creative Common Attribution 4.0 International License.

\section{Introduction}

Under competitive business environment, technological innovation and satisfaction of customer needs are the keys to survival and success for firms, especially for high-tech firms. The success of new product development (NPD) is important to maintain a competitive edge and to make a decent profit for a firm because new products are usually a source of new sales and profits.

NPD contains several alternative NPD process models. It is possible to recognize the similarities between the different models. What they have in common is that the NPD process begins with an idea to build a product that meets specific needs (or create new needs for radically innovative products) defined by customers and or the manufacturer, and ends when the product is launched on the market.

Companies that are able to bring new products, that satisfy the expectations of the customer fast and efficient to the market, will manage to succeed in the intense and dynamic global environment in 
which it operates. The US based Product Development \& Management Association (PDMA) defines New Product Development as "a disciplined and defined set of tasks and steps that describe the normal means by which a company repetitively converts embryonic ideas into saleable products or services" (T. Østeras et al., 2004).

Therefore, relationship between marketing and production departments in any organization seems necessary in order to provide goods, which can meet customer's satisfaction in the best possible form. The important relationship between production and marketing has been known in the late 1960s, i.e., when Japanese used QFD to design products with features and taste of customers. They believe that constant changes resulting from the globalization process and innovation in technology, which affects business environment severely, force organizations to create new competitive advantages in order to maintain their situation in the market.

Jeddi et al. (2014) proposed a fuzzy QFD and ANN approach for new product's Specification selection. This paper proposes significant contribution of that approach to forecast specification.

Given the above subjects, consider requirements and restrictions of producer to meet demands of customer according to the features as expected by customer from product. It was decided to use this model in a company as producer of Digital Scales.

The rest of the paper is organized as follows: Section II, III describes the procedure for the new product specifications forecast and proposes a decision support system, called new product specification forecast system (NPSFS), to help this task. Section IV presents data preparation and analysis. Section IV shows the results of NPSFS on a real-world case. Finally, Section V offers our conclusions.

\section{New product specification forecast system}

The structure of NPSFS is shown in Figure 01 The required data are initially prepared and make the QFD Matrix. The central relation matrix of QFD is calculated by Fuzzy AHP. The approval of these results and final decision is made by the decision maker (DM).

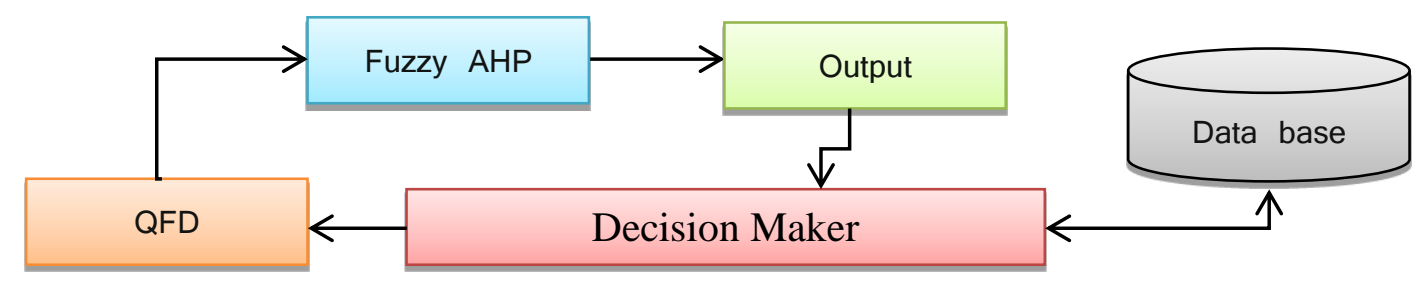

Figure 01. New Product Specification Forecast model.

The basic accepted customer attributes (Table 01) in the model are extracted from reviewed literature and the interviews for the Digital Scale experts. Unit Price is one of important attributes for customers but we not consider it in this paper.

For engineering characteristics, the specification of 20 Digital Scales collected from Manual and website of Iranian producer and main specification is shown in Table 02. 
Table 02. Digital scales specifications

\begin{tabular}{|c|c|}
\hline $\begin{array}{l}\text { 1. } \text { Printer } \\
\text { - Type : receipt , Label } \\
\text { - Width : } 57,80 \mathrm{~mm} \\
\end{array}$ & $\begin{array}{l}\text { 5. Keypad } \\
\text { - Type : Flat, Raised } \\
\text { - } \quad \text { Position : Up, Down of plate }\end{array}$ \\
\hline $\begin{array}{ll}\text { 2. } & \text { Display } \\
\text { - } & \text { Type : LED , LCD } \\
\text { - } & \text { Digit Numbers } \\
\text { - } & \text { Position : Up, Down of plate }\end{array}$ & $\begin{array}{l}\text { 6. Weight } \\
\text { - Max : } 30,40,50,75 \mathrm{~kg} \\
\text { - Accuracy: } 5,10,20 \mathrm{~g}\end{array}$ \\
\hline $\begin{array}{l}\text { 3. Function } \\
\text { - } \text { Count } \\
\text { - Tare } \\
\text { - Zero } \\
\text { - PuU } \\
\text { - } \text { Refund } \\
\text { - Storage control } \\
\text { - Multi Customer } \\
\text { - Calculator } \\
\text { - Report }\end{array}$ & $\begin{array}{l}\text { 7. I/O interface } \\
\text { - Cash drawer } \\
\text { - Scanner } \\
\text { - USB } \\
\text { - Memory Card } \\
\text { - PC software } \\
\text { - Ethernet } \\
\text { - External Printer }\end{array}$ \\
\hline $\begin{array}{l}\text { 4. } \\
\text { PLU } \\
\text { - Max Qty of PLU: } 100,200,500,1000\end{array}$ & $\begin{array}{l}\text { 8.General } \\
\text { - Power Supply } \\
\text { - Rechargeable battery } \\
\text { - Operating temperature } \\
\text { - Environment humidity } \\
\text { - Weight } \\
\text { - Dimension }\end{array}$ \\
\hline
\end{tabular}

\section{An integrated fuzzy AHP-QFD model}

\section{01 QFD}

In a complete QFD system, there are typically four phases: product planning, part deployment, process planning and production planning. Each phase contains a matrix, called HOQ. The systematic procedure for the first HOQ contains seven steps:

a. Obtain customer attributes (CAs).

b. Develop engineering characteristics (ECs). To represent the evaluating criteria that should be considered to satisfy the customer needs.

c. Construct the pair wise comparison matrices between CAs and ECs using Satty's nine -point scale.

d. Compute $R_{i j}$ the relationship between $i$ customer attributes (CAs) and the $j$ engineering characteristics (ECs) in the central relationship matrix. $\mathrm{R}_{\mathrm{ij}}$ Is geometric mean of Weights of Fuzzy AHP for all decision-maker participated in the decision making process.

e. Input importance of CAs (Input value is 1 5)

f. Wj, the importance of ECs is calculated by using Eq. (1) :

$\mathrm{W}_{\mathrm{j}}=\sum_{\mathrm{i}=1}^{\mathrm{m}} \mathrm{R}_{\mathrm{ij}} \mathrm{CA}$

g. Normalize the degree of importance of technical criteria, $\mathrm{Wj}$ :

$\overline{\mathrm{W}}_{\mathrm{j}}=\frac{\mathrm{W}_{\mathrm{j}}}{\sum_{\mathrm{j}=1}^{\mathrm{n}} \mathrm{W}_{\mathrm{j}}} \times 100$

QFD has been applied abundantly. For example, Wang and Lin (2007) constructed a defects tracking matrix (DTM) based on the HOQ to directly connect manufacturing technologies with quality defects 
inside a mass customization production (MCP) module. Lu et al. (2007) suggested the use of QFD to match customer desires with design configurations in proposing a framework for simulation modeling of a transporter-constrained supply chain of customized products.

Because of the interrelationships among CAs and among ECs, AHP is used in some works (Chuang, 2001). This paper, a general super matrix approach, can tackle more complicated problems (Saaty, 1996). Nevertheless, the input variables are assumed to be precise and are treated as numerical data under the two approaches. However, human decision making often contains ambiguity and uncertainty, and conventional AHP is inadequate to explicitly capture the importance assessment of CAs and ECs. To confront this problem, a new trend of studies is to incorporate fuzzy set theory into AHP-QFD .In this paper,design and calculation of QFD matrix is done by QFD 2000 application trial version

\section{02 Fuzzy AHP}

In the conventional AHP method first is developed by Saaty (1980). Pairwise comparisons for each level with respect to the goal of the best alternative selection are conducted using a nine-point scale. Different types of fuzzy membership functions have been used in fuzzy logic. However, three types are most common: monotonic, triangular, and trapezoidal. Because the fuzzy set is a convex function, the trapezoidal function or triangular function approaches the convex function well. The triangular fuzzy numbers are more convenient in applications due to their computational simplicity, and they are useful in promoting representation and information processing in a fuzzy environment (Taha and Rostam, 2011).

The characteristics and membership function of the triangular fuzzy number are expressed by Eq. (3):

$$
\mu(\mathrm{x})=\left\{\begin{array}{cc}
(x-l) /(m-l), & l \leq x \leq m \\
(u-x) /(u-m), & m \leq x \leq u \\
0, & \text { Otherwise }
\end{array}\right.
$$

By introducing the $\alpha$-cut and defining the interval of confidence at confidence level $\alpha$, the triangular fuzzy number can be characterized by Eq. (2).The $\alpha$-cut is known to incorporate the experts or decision maker(s) confidence over his/her preference or the judgments.

$$
\forall \alpha \epsilon[0,1] \tilde{A}_{a}=\left[l_{\omega} \mu_{a}\right]=[(m-l) a+l, \mu-(\mu-m) a]
$$

The degree of satisfaction can be estimated from the decision maker by index of optimism $\lambda$ by Eq. (5), where its value range is $0<\lambda<1$. The larger the index $\lambda$, the higher the degree of satisfaction:

$$
\tilde{a}^{a}{ }_{i j}=\lambda a^{a}{ }_{i j u}+(1-\lambda) a^{a}{ }_{i j l}, \forall \lambda \epsilon[0,1]
$$

The matrix $\tilde{A}$ is reconstructed by using the $\tilde{a}^{a}{ }_{i j}$ equationabove, and the degree of satisfaction can be estimated setting the index of optimism $\lambda$ and fixing $\alpha$. Therefore:

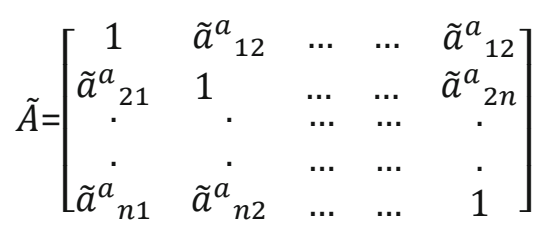

The five triangular fuzzy numbers and their reciprocal scale are defined with the corresponding membership function as shown in Table 03. 
Table 03. Definition and membership functions of fuzzy numbers

\begin{tabular}{llll}
\hline $\begin{array}{l}\text { Fuzzy } \\
\text { numbers }\end{array}$ & \multicolumn{1}{c}{ Definition } & $\begin{array}{l}\text { Membership } \\
\text { function }\end{array}$ & Reciprocal scale \\
\hline$\tilde{1}$ & Equally important & $(1,1,2)$ & $(1 / 2,1,1)$ \\
$\tilde{3}$ & $\begin{array}{l}\text { Moderately } \\
\text { important }\end{array}$ & $(2,3,4)$ & $(1 / 4,1 / 3,1 / 2)$ \\
$\tilde{5}$ & Strongly important & $(4,5,6)$ & $(1 / 6,1 / 5,1 / 4)$ \\
$\tilde{7}$ & $\begin{array}{l}\text { Very Strongly } \\
\text { important }\end{array}$ & $(6,7,8)$ & $(1 / 8,1 / 7,1 / 6)$ \\
$\tilde{9}$ & Extremely important & $(8,9,10)$ & $(1 / 10,1 / 9,1 / 8)$ \\
$\tilde{2}, \tilde{4}, \tilde{6}, \tilde{8}$ & $\begin{array}{l}\text { Intermediate } \\
\text { values }\end{array}$ & & \\
\hline
\end{tabular}

Calculating the overall priority weight for each alternative (AW) by multiplying the vector of criteria weight (CW) by the matrix of alternative evaluation weights (AEW) using the equation below:

$$
A W_{k}=\sum_{i=1}^{n} C W_{i}+A E W_{i k}
$$

Where, $\mathrm{n}=$ number of criteria, $\mathrm{m}=$ number of alternatives, and $\mathrm{k}=1,2, \ldots, \mathrm{m}$.

In order to identify the consistency ratio of a matrix, first, the matrix consistency index (CI) is found by:

$$
C I=\left(\lambda_{\max }\right)+(n-1)
$$

The consistency index of a randomly generated reciprocal matrix with reciprocal forces is called the random index (RI) and is calculated using the matrix order (n) and the table explained by Saaty.

So, the matrix consistency ratio (CR) is calculated using:

$$
C R=C I / R I
$$

A consistency ratio of 0.1 or less is considered acceptable. Then compute geometric mean of Weights of Fuzzy AHP for group decision making. To find the weights of the QFD relationship matrix by the fuzzy AHP model, a program is developed using MATLAB.

\section{Case study: new product specification forecast system}

\section{01. The selection of QFD factors (CAs \& ECs)}

To recognize the main needs of customers (CAs), some questionnaires were distributed among 30 of them. As table 01 , only 11 main needs were propounded out of 17 presented needs. The 6 important needs of the customers to determine the technical features of the new product are as follows:
a. The most suitable weigh
b. High accuracy
c. Clear and readable display
d. Appropriate and resistant keyboard
e. Enough Memory (PLU)
f. Immediate and accurate after sales service

To determine the engineering characteristics (ECs) in providing the customer's needs, other questioners were prepared and distributed among 25 active sales agents who were chosen by the 
manager of the company. Only 15 sale agents replied. According to the most chosen items, the following results to determine the characteristics of the product were obtained. These features are presented in table 04.

\begin{tabular}{ll}
\hline Table 04. & The product 's features \\
\hline Max weight & $30,50 \mathrm{~kg}$ \\
Accuracy & $5,10 \mathrm{~g}$ \\
Display & LED Up, LED down \\
Keyboard & Press Down, Flat Down \\
PLU & 100,1000 \\
\hline
\end{tabular}

\section{02. The ranking of factors using the FAHP-QFD}

The combination of CAs and ECs made QFD matrix and it's shown in table 05.

Table 05. QFD ( house of quality )

\begin{tabular}{|c|c|c|c|c|c|c|c|c|c|c|c|}
\hline \multirow{3}{*}{\multicolumn{2}{|c|}{ Matrix QFD }} & \multicolumn{10}{|c|}{ Engineering characteristics } \\
\hline & & \multirow{2}{*}{\multicolumn{2}{|c|}{ Max weight }} & \multirow{2}{*}{\multicolumn{2}{|c|}{ Accuracy }} & \multirow{2}{*}{\multicolumn{2}{|c|}{ Display }} & \multirow{2}{*}{\multicolumn{2}{|c|}{ Keyboard }} & \multirow{2}{*}{\multicolumn{2}{|c|}{ PLU }} \\
\hline & & & & & & & & & & & \\
\hline \multirow{6}{*}{ 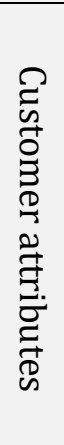 } & $\begin{array}{l}\text { Suitable Max } \\
\text { weight }\end{array}$ & & & & & & & & & & \\
\hline & High accuracy & & & & & & & & & & \\
\hline & Readable display & & & & & & & & & & \\
\hline & $\begin{array}{l}\text { appropriate and } \\
\text { resistant keyboard }\end{array}$ & & & & & & & & & & \\
\hline & $\begin{array}{l}\text { enough Memory } \\
\text { (PLU) }\end{array}$ & & & & & & & & & & \\
\hline & After sales service & & & & & & & & & & \\
\hline
\end{tabular}

Seven experts on Scale production participated in the filling Matrixes. A questionnaire based on the proposed hierarchy structure was formulated using fuzzy numbers. The next Step for the decision makers are assigning the preference score for the evaluation ECs with respect to each evaluation.After the data have been collected from the decision makers, 48 matrices for the ECs' comparisons are built. The priority weights of the selected features based on fuzzy AHP model are determined using the program in MATLAB Software as follows:

Step 1. Preparing the input data to program, the first decision maker's preference scores are presented in Table 06.

Table 06. comparison matrix for the ECs with respect to the first Customer attribute-Suitable Max weight

\begin{tabular}{|c|c|c|c|c|c|c|c|c|c|c|c|}
\hline & & \multicolumn{2}{|c|}{$\begin{array}{l}\text { Max } \\
\text { weight }\end{array}$} & \multicolumn{2}{|c|}{ Accuracy } & \multicolumn{2}{|c|}{ Display } & \multicolumn{2}{|c|}{ Keyboard } & \multicolumn{2}{|l|}{ PLU } \\
\hline & & $\begin{array}{l}30 \\
\mathrm{~kg}\end{array}$ & $\begin{array}{l}50 \\
\mathrm{~kg}\end{array}$ & $5 g$ & $10 \mathrm{~g}$ & $\begin{array}{l}\text { LED } \\
\text { Up }\end{array}$ & $\begin{array}{l}\text { LED } \\
\text { down }\end{array}$ & $\begin{array}{l}\text { Press } \\
\text { Down }\end{array}$ & $\begin{array}{l}\text { Flat } \\
\text { Down }\end{array}$ & 100 & 1000 \\
\hline \multirow{2}{*}{$\begin{array}{l}\text { Max } \\
\text { weight }\end{array}$} & $30 \mathrm{~kg}$ & 1 & 1 & 5 & 5 & 5 & 5 & 5 & 5 & 5 & 5 \\
\hline & $50 \mathrm{~kg}$ & 1 & 1 & 5 & 5 & 5 & 5 & 5 & 5 & 5 & 5 \\
\hline \multirow{2}{*}{ Accuracy } & $5 g$ & 0 & 0 & 1 & 1 & 1 & 1 & 1 & 1 & 1 & 1 \\
\hline & $10 \mathrm{~g}$ & 0 & 0 & 0 & 1 & 1 & 1 & 1 & 1 & 1 & 1 \\
\hline Display & LED Up & 0 & 0 & 0 & 0 & 1 & 1 & 1 & 1 & 1 & 1 \\
\hline
\end{tabular}




\begin{tabular}{|l|l|l|l|l|l|l|l|l|l|l|l|}
\hline & $\begin{array}{l}\text { LED } \\
\text { down }\end{array}$ & 0 & 0 & 0 & 0 & 0 & 1 & 1 & 1 & 1 & 1 \\
\hline \multirow{5}{*}{ Keyboard } & $\begin{array}{l}\text { Press } \\
\text { Down }\end{array}$ & 0 & 0 & 0 & 0 & 0 & 0 & 1 & 1 & 1 & 1 \\
\cline { 2 - 13 } & $\begin{array}{l}\text { Press } \\
\text { Down }\end{array}$ & 0 & 0 & 0 & 0 & 0 & 0 & 0 & 1 & 1 & 1 \\
\hline \multirow{2}{*}{ PLU } & 100 & 0 & 0 & 0 & 0 & 0 & 0 & 0 & 0 & 1 & 1 \\
\cline { 2 - 12 } & 1000 & 0 & 0 & 0 & 0 & 0 & 0 & 0 & 0 & 0 & 1 \\
\hline
\end{tabular}

Step 2. The weights of ECs for the first decision maker are shown in Tables 07. If CI > 0.1, the program is showed error, the related matrix would refill by the decision maker

Table 07. ECs' weight for the first decision maker's judgment with respect to the first Customer attribute-Suitable Max weight

\begin{tabular}{cccccccccc}
\hline $30 \mathrm{~kg}$ & $50 \mathrm{~kg}$ & $5 \mathrm{~g}$ & $10 \mathrm{~g}$ & LED Up & LED down & Press Down & Flat Down & 100 & 1000 \\
\hline 0.5 & 0.5 & 0 & 0 & 0 & 0 & 0 & 0 & 0 & 0 \\
\hline
\end{tabular}

Step 3. Repeating the steps from (1) to (2) for the remaining decision makers (number 2 to number 7).

The final results for the ECs' weights for the seven decision makers are shown in Table 08.

Table 08. ECs' weights of for all decision makers with respect to the first Customer attributeSuitable Max weight

\begin{tabular}{|l|l|l|l|l|l|l|l|l|l|l|l|}
\hline & \multicolumn{2}{|l|}{ Max weight } & \multicolumn{2}{l}{ Accuracy } & \multicolumn{2}{l|}{ Display } & \multicolumn{2}{l|}{ Keyboard } & \multicolumn{2}{l|}{ PLU } \\
\cline { 2 - 13 } & $30 \mathrm{~kg}$ & $50 \mathrm{~kg}$ & $5 \mathrm{~g}$ & $10 \mathrm{~g}$ & $\begin{array}{l}\text { LED } \\
\text { Up }\end{array}$ & $\begin{array}{l}\text { LED } \\
\text { down }\end{array}$ & $\begin{array}{l}\text { Press } \\
\text { Down }\end{array}$ & $\begin{array}{l}\text { Flat } \\
\text { Down }\end{array}$ & 100 & 1000 \\
\hline DM1 & 0.4693 & 0.5307 & 0 & 0 & 0 & 0 & 0 & 0 & 0 & 0 \\
\hline DM2 & 0.5360 & 0.4640 & 0 & 0 & 0 & 0 & 0 & 0 & 0 & 0 \\
\hline DM3 & 0.5300 & 0.4700 & 0 & 0 & 0 & 0 & 0 & 0 & 0 & 0 \\
\hline DM4 & 0.5325 & 0.4675 & 0 & 0 & 0 & 0 & 0 & 0 & 0 & 0 \\
\hline DM5 & 0.4671 & 0.5329 & 0 & 0 & 0 & 0 & 0 & 0 & 0 & 0 \\
\hline DM6 & 0.5 & 0.5 & 0 & 0 & 0 & 0 & 0 & 0 & 0 & 0 \\
\hline DM7 & 0.5 & 0.5 & 0 & 0 & 0 & 0 & 0 & 0 & 0 & 0 \\
\hline $\begin{array}{l}\text { Overall } \\
\text { weight }\end{array}$ & 0.5042 & 0.4942 & 0 & 0 & 0 & 0 & 0 & 0 & 0 & 0 \\
\hline
\end{tabular}

In this investigation, the results obtained from the previous steps (fuzzy AHP model) are used to denote the relationship between What's and How's. To use the QFD 2000 software, we determined and entered the quantities in the Software as table 09. The HoQ matrix is developed as Figure 02.

\section{Table 09. Determine importance of HoQ matrix according to results of fuzzy AHP model}

\begin{tabular}{|l|l|l|}
\hline Relation & Mark & Overall weight of fuzzy AHP model \\
\hline Strong & $\bullet$ & $0.75 \sim 1$ \\
\hline Medium & $\bigcirc$ & $0.5 \sim 0.75$ \\
\hline Weak & $\triangle$ & $0.25 \sim 0.5$ \\
\hline $\begin{array}{l}\text { No } \\
\text { relation }\end{array}$ & & $0 \sim 0.25$ \\
\hline
\end{tabular}




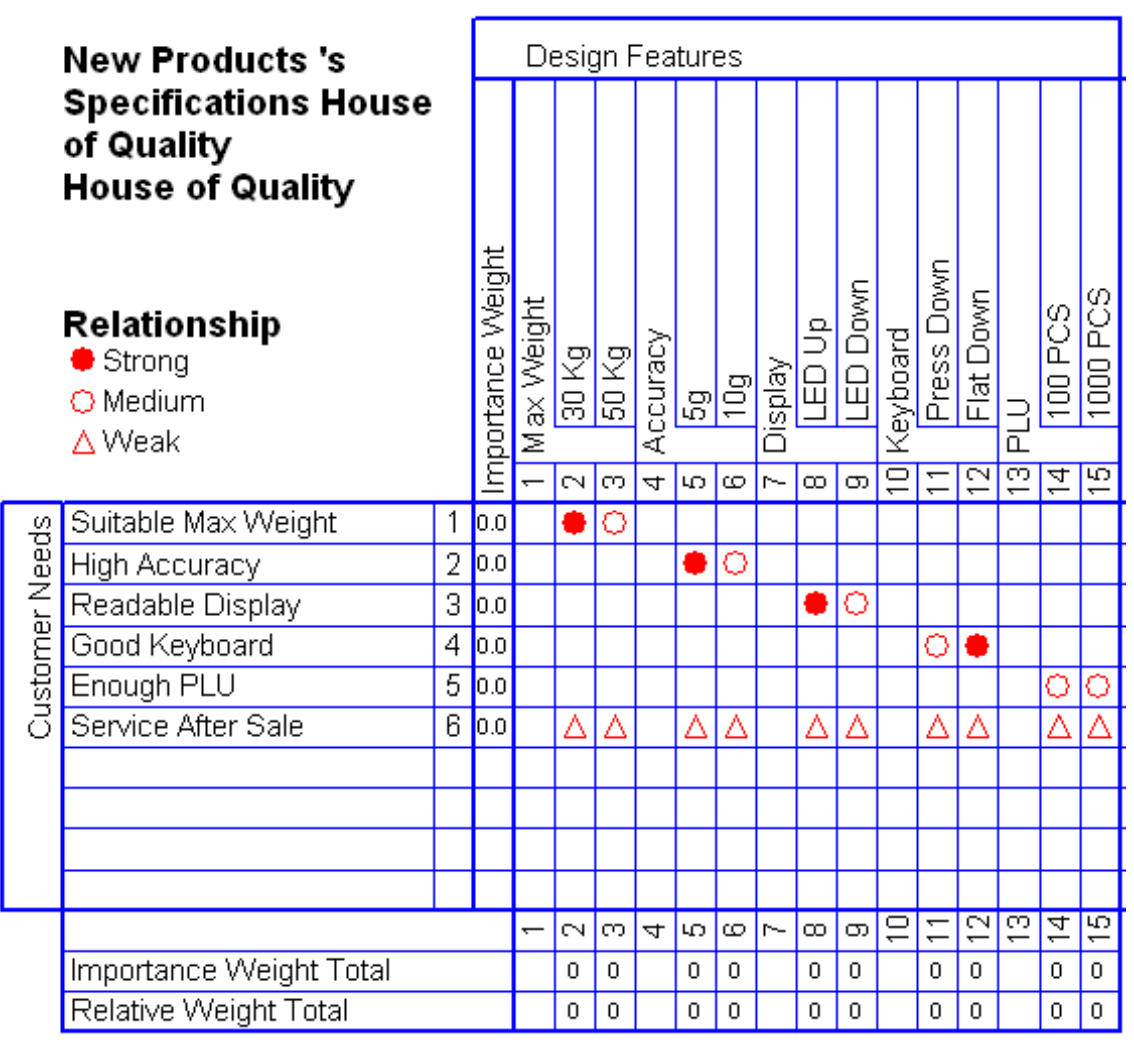

Figure 02. HoO matrix for the evaluation alternatives.

These results clearly show the accuracy and power of the proposed model which is based on the developed a Fuzzy AHP program. So, NPSFS by combining the fuzzy AHD and QFD in this work can be used as an active tool to select the most suitable Specification for new product to satisfy customer's needs.

\section{Conclusion}

Customer needs and wants are sensitive and complex. If a firm can understand them and make efforts to fulfill customer demands and provide friendly service, then customers will be more supportive and loyal to the enterprise. During the process of development from the product concept to the actual product, the customer can only passively receive new information, and can only select from the products that are currently on sale in the market. No matter which type of product, the customer cannot individually come up with a product concept and then develop it. New Product Forecast System, a systematic framework that incorporates Fuzzy AHP into QFD for new product development. Through literature review and interview with experts, lists of factors are prepared, including customer attributes, engineering characteristics, parts characteristics, key process operations and production requirements. The results are used to construct the first houses of QFD, and the priorities of the factors can be calculated through FAHP. NPSFS is examined by a case study in a digital scale manufacturer in IRAN. The results show the important customer attributes, engineering characteristics, parts characteristics, key process operations and production requirements in designing a new product. Those factors with higher priorities should especially be focused on. In conclusion, the proposed model can help a firm systematically consider relevant NPD information and effectively determine key specifications for designing and manufacturing of new products.

\section{References}

[1]. Chuang, P. T. (2001). Combining the analytic hierarchy process and quality function deployment for a location decision from a requirement perspective. International Journal Advance Manufacturing Technology, 18, 842-849. http://dx.doi.org/10.1007/s001700170010 
[2]. Jeddi, K. Y., Alborzi, M \& Dadfar, R. (2014). A designing decision support system for new product specifications selection: Using Fuzzy AHP-QFD and ANN (Case Study: Arvin Dosari Co., Digital Scale Producer). International Journal of Innovative Technology and Research, 2(1), 663 - 673.

[3]. Lu, R. F., Petersen, T. D. \& Storch, R. L. (2007). Modeling customized product configuration in large assembly manufacturing with supply-chain considerations. Int. J. Flex. Manuf. Syst., 19, 685712. http://dx.doi.org/10.1007/s10696-008-9041-0

[4]. Saaty, T. L. (1980). The Analytic Hierarchy Process, McGraw-Hill, New York, USA.

[5]. Saaty, T. L. (1996). Decision making with dependence and feedback: the analytic network process. RWS Publications, Pittsburgh.

[6]. T. Østeras, Murthy, D. N. P. \& Rausand, M. (2004). Reliability performance and specifications in new product development. Retrieved 10 March 2016 from http://frigg.ivt.ntnu.no/ross/reports/ReliabilitySpecifications.pdf

[7]. Taha, Z. \& Rostam, S. (2011). A Fuzzy AHP-ANN Based Decision Support System for Machine Tool Selection in a Flexible Manufacturing Cell. International Journal of Advanced Manufacturing Technology, 57, 719- 733. http://dx.doi.org/10.1007/s00170-011-3323-5

[8]. Wang, H. \& Lin, Z. (2007). Defects tracking matrix for mass customization production based on house of quality. Int. J. Flex. Manuf. Syst., 19, 666-684. http://dx.doi.org/10.1007/s10696-0079025-5 